Зацікавити студента, долаючи характерне для технічних ВНЗ скептичне ставлення слухачів до хімії, залучити його до процесу навчання, зробити предмет вивчення зрозумілим i, як результат, навчити - це основа аксіологічної задачі віднайдення способів і методів викладання навчального матеріалу з предмета. Із цієї причини добір лекційного матеріалу, матеріалу в навчальних посібниках відбувається, виходячи 3 цінності, важливості і значущості знань із хімії для майбутньої діяльності інженера, а рівень і стиль викладання сприяє аксіологічній мотивації вивчення хімії. Тому в низці випадків під час компонування деяких розділів хімії робиться вибір на користь аксіологічно доступного розуміння матеріалу, який викладається [4].

Наведені вище підходи значною мірою підвищують мотивацію у вивченні дисципліни, позитивно впливають на зростання успішності з предмета, i дозволяють досягнути головної мети - навчити студентів вчитися та забезпечити достатній рівень знань, що гарантує подальше вивчення інших дисциплін у технічному ВНЗ.

\title{
Література
}

1. Гран Р. Й. Реформы образования и старшая школа / Р.Й. Гран. - М. : Недра, 2003. - 154 с. 2. Днепров Э. Д. Образовательный стандарт в контексте обновления содержания образования /Э. Д. Днепров. - М. : Институт новых образовательных систем, 2002. - 26 с. 3. Забезпечення якості вищої освіти - важлива умова інноваційного розвитку держави і суспільства // Інформаційно-аналітичні матеріали до засідання підсумкової колегії Міністерства освіти і науки, 1-2 березня 2007 року. - Київ, 2007. - 96 с. 4. Коржуев А. В. Традиции и инновации в высшем профессиональном образовании / А. В. Коржуев, В. А. Попков. - М. : Изд-во Моск. ун-та, 2003. 300 с. 5. Кузьменко Н. Е. О некоторых проблемах реформирования общего и высшего химического образования в России / Н. Е. Кузьменко, О. Н. Рыжова, В. В. Лунин. // Современные тенденции развития химического образования. - Кишинэу: Univers Pedagogic, 2005. - 136 с. 6. Макарова Л. Л. Совершенствование химического образования как важная составляющая концепции модернизации высшего образования / Л. Л. Макарова, О. А. Овечкина. // Вестник Удмуртского университета, серия «Психология и педагогика». - 2008. - № 9. - С. 53-58. 7. Сергеев Г. Б. Нанохимия / Г. Б. Сергеев. - М. : Изд-во Моск. ун-та, 2003. - 288 с. 8. Deters K. M. What Should We Teach in High School Chemistry? / K. M. Deters // J. Chem. Educ., 2003, v. 80, № 10. - P. 1153-1555. 9. Mason D. S. What is Chemical Education? / D. S. Mason // J. Chem. Educ., 2003, v. 80 , № 5. - P. 465 .

УДК [377:61]:37.032

I. I. Черемісова, аспірант,

Харківський наиіональний педагогічний університет імені Г. С. Сковороди

\section{ОРГАНІЗОВАНІСТЬ ЯК ОДНА 3 ГОЛОВНИХ ПРОФЕСІЙНО ВАЖЛИВИХ ЯКОСТЕЙ МЕДИЧНОГО ПРАЦІВНИКА}

Черемісова I. І. Організованість як одна 3 головних професійно важливих якостей медичного працівника.

У статі розглянуто професійно важливі якості медичного працівника, визначено ці якості. Розкрито суть і зміст професійних якостей медичного працівника.

Ключові слова: студент, професійні якості медичного працівника, самостійність, організованість.

Черемисова И. И. Организованность как одна из главных профессионально важных качеств медицинского работника.

В статье рассмотрены профессионально важные качества медицинского работника, определены эти качества. Раскрыты суть и содержание профессиональных качеств медицинского работника.

Ключевые слова: студент, профессиональные качества медицинского работника, самостоятельность, организованность. 
Cheremisova I. I. Organization as one of the main important professional qualities of health worker.

The article touches upon medical worker's the most important professional qualities. The concept of medical worker's qualities is investigated here.

Key words: student, medical worker's qualities, individuality, organization.

Нова парадигма освіти, зумовлюючи перехід до особистісно зорієнтованої моделі, акцентує пріоритетність завдань своєчасної реалізації й розвитку особистісного потенціалу студента, його здібностей до засвоєння знань. Завдання гуманізації й індивідуалізації навчально-виховного процесу вимагають обов'язкового врахування індивідуальних особливостей кожного студента, створення умов для ii повноцінного особистісного розвитку, становлення як суб'єкта діяльності.

Аналіз останніх досліджень i публікацій. Постановка проблеми студентства як особливої соціально-психологічної та вікової категорії належить психологічній школі Б. Ананьєва. У дослідженнях таких науковців, як Б. Ананьєва, Ю. Кулюткіна, А. Реана, В. Рєпкіна, Є. Степанової, а також у працях П. Просецького, В. Сластьоніна, В. Якуніна та інших зібрано великий емпіричний матеріал спостережень, надаються результати експериментів та теоретичних узагальнень цієї проблеми. Дані цих досліджень дозволяють схарактеризувати студента як особливого суб'єкта навчальної діяльності із соціально-психологічного та психолого-педагогічного аспектів.

Сутність, зміст і структура організованості як якості особистості розглядаються в роботах С. Ільїна, А. Ковальова, В. Мясищева, В. Селіванова, С. Якобсон та ін. Так, А. Лутошкін, І. Мангутов, Л. Уманський розглядають проблему організованості в процесі вивчення особливостей організаторської діяльності; С. Чернер - під час формування ділових якостей особистості; Ю. Васильєв і І. Мельничук звертаються до організованості, досліджуючи питання економічного виховання та освіти. Ряд науковців пов'язуює організованість із навчальною діяльністю, але не 3 професійною спрямованістю. А. Алфьоров розглядає організованість як необхідну передумову виховання відповідального ставлення студента до навчання; Є. Рабунский пов'язує виховання організованості студентів із самостійною навчальною діяльністю; М. Шилова уважає, що організованість в навчанні відображає ставлення студента до розумової праці.

Mema cmammi - визначити головні якості медичних працівників, розкрити суть та зміст; розглянути морально-психологічні, пізнавальні, інтелектуальні, емоційно-вольові та комутативні якості.

Специфіка багатьох професій накладає відбиток на модель фахівця, додаючи деякі штрихи до характеру особистості, пов'язані з особливостями професії: наприклад, організованість, дисциплінованість, наполегливість, ініціативність, спостережливість, охайність, обсяг пам'яті тощо. У деяких випадках підкреслюється важливість ступеня здоров'я, контактність, стійкість до стресів тощо.

Студентський вік (18-25 років) є особливим періодом життя людини, оскільки становить першу ланку дорослого життя [2].

Професія медичного працівника -найдавніша і найшанованіша. Вона $є$ вираженням властивої людині потреби надати допомогу стражденному. Засновник медицини Гіппократ писав: «Медицина воїстину є найрозсудливішим з усіх мистецтв». У всі часи у всіх народів лікування цінувалося надзвичайно високо. Ще Гомер писав: «Багатьох воїнів вартий один лікар-майстер» [1].

3-поміж позитивних потенційних можливостей розвитку у студентському віці важливу роль відіграє організованість, оскільки $є$ найважливішим компонентом загальних здібностей.

За психолого-педагогічною сутністю і способами формування організованість є складною та багатогранною характеристикою. Водночас, маємо визнати, що донині феномен організованості $є$ маловивченим унаслідок того, що у психолого-педагогічній науці немає єдиновизначеної думки відносно природи окресленої властивості особистості. 
У тлумачному словнику української мови термін організованість - створювати, засновувати, об'єднувати 3 певною метою, вводити порядок, підпорядковувати нормам [4].

Особистісна складова моделі фахівця забезпечується навчально-виховним процесом, а також залежить від спадковості, сімейного виховання, станом суспільства, наявності прикладів для наслідування.

Однією з необхідних рис медичного працівника $є$ професійна чесність, яка повинна грунтуватися на провідних принципах його діяльності - гуманізмі, моральному обов'язку, постійному точному виконанні своїх обов'язків, при цьому інтереси хворого i громадського здоров'я повинні бути вищими за його особистих інтересів, переживань $\mathrm{i}$ почуттів. Медичний працівник має пам'ятати не лише про те, що доля здорової або хворої людини, ввіреної йому, залежить від його знань і дій, але і про те, що він повинен бути першим і суровим суддею своїх вчинків, усієї професійної діяльності, аналізуючи ії̈ перед самим собою і совістю. Тільки висока самокритичність і абсолютна чесність допоможуть йому правильно оцінити роботу і виконувати обов'язки.

Із урахуванням думок науковців і аналізу медичної практики нами зроблено висновок про те, що медичні працівники повинні володіти такими якостями: колегіальність, доброзичливість, професійна репутація, вимогливість, довіра, взаємопідтримка, взаємодопомога, здатність визнавати свої помилки тощо.

Підкреслимо, що психологічний потенціал медичного працівника забезпечує ефективність його діяльності та реалізації професійних функцій. Структурно такий психологічний потенціал утворюється з таких якостей:

1) індивідуальної професійної концепції;

2) морально-психологічних якостей;

3) пізнавальних та інтелектуальних якостей;

4) емоційно-вольових якостей;

5) комунікативних якостей.

1. Індивідуальна професійна концееція медичного працівника становить суб'єктивне, особистісне бачення системи основних професійних проблем, змісту, способів і прийомів праці, труднощів в організації взаємодії та особистої праці. Індивідуальна професійна концепція у сформованому вигляді розкриває особистісний зміст діяльності медичного працівника, впливає на мотивацію праці, постановку конкретних службових і життєвих цілей.

2. Морально-психологічні якості відображають моральні зобов'язання та етичні норми поведінки медичного працівника. Мова йде про належне поводження 3 позиції моральності, професійної етики, конкретних норм моралі, гуманного ставлення до іншої людини. Моральну основу поведінки медичного працівника становлять такі моральнопсихологічні якості: почуття професійного обов'язку; професійна честь; справедливість; принциповість, чесність, порядність; співчуття і співпереживання; мужність; організованість; почуття товариства; гуманність і співчуття і тощо.

3. Пізнавальні та інтелектуальні якості. Професійна пам'ять працівника на обличчя, зовнішність людини, числа (дати народження, наприклад), ім'я, по батькові, прізвище тощо дозволяє ефективно розв'язати професійні завдання. Продуктивне мислення працівника характеризується такими якостями: гнучкість, широта, критичність, швидкість, кмітливість, прогностичність тощо.

4. Емоційно-вольові якості. Діяльність медичного працівника пов'язана зі стресами і негативними переживаннями. Поміж стрес-факторів, пов'язаних 3 професійною діяльністю, переважно називають велику завантаженість роботою і відсутність вільного часу; труднощі, пов'язані 3 виконанням обов'язків на новій посаді; підвищену відповідальність за прийняті рішення; відчуття невідповідності між тим, що повинен, що хотів би і що реально робить; необхідність часто йти на компроміси в ім'я збереження службової кар'єри; недолік зворотної інформації про свою діяльність; незадовільні 
стосунки з керівництвом; невизначеність посадового зростання; несприятливий соціальнопсихологічний клімат у професійному колективі тощо. Працівнику слід звертати увагу на розвиток у себе таких емоційно-вольових якостей, як: організованість, рішучість, наполегливість, самовладання, емоційна врівноваженість, витримка, витривалість, обачність, холоднокровність, впевненість у власних силах тощо.

5. Комунікативні якості сприяють ефективності ділової взаємодії: впевненість; незалежність; скромність; установка на співробітництво; готовність допомогти; співчуття; обов'язковість; володіння технікою спілкування; чуйність; дбайливість; справедливість; щирість у спілкуванні; активність у спільній діяльності; товариськість; послідовність; тактовність. Ускладнюють ділову взаємодію наступні якості: скептицизм; сором'язливість; покірність; переоцінка своїх можливостей; агресивність; прагнення до домінування; самовдоволення; відособленість; запальність; образливість; недовірливість; підозрілість; боязкість; грубість; поблажливість; замкнутість; скритність.

Зазначимо, що професійна робота медичного працівника пов'язана не тільки 3 великими фізичними навантаженнями, але і зі значним емоційним напруженням, що $є$ наслідком спілкування з пацієнтами. Як відомо, під час хвороби більшість людей стають дратівливими, вимогливими, вразливими. Щоб знайти 3 ними контакт, медичний працівник повинен бути терплячим і спокійним до певною мірою неадекватної поведінки цих людей.

На думку А. Лутошкіна, ці якості особистості які дозволять людині (студенту) швидко, надійно, впевнено виконувати будь-яку справу, доводити іiі до кінця. На нашу думку, перераховуючи якості в медичного працівника потрібні, щоб досягти успіху в навчанні, праці, але й не повинні переходити у свою протилежність (слабовілля, безініціативність, замкнутість, неорганізованість тощо):

- компетентність - знання тієї справи, яку потрібно організувати;

- активність - уміння діяти енергійно, наполегливо у розв'язанні практичних завдань;

- ініціативність - особливе творче виявлення активності, висунення ідей, пропозицій;

- товариськість - відкритість, готовність спілкуватися, потреба мати контакти 3 людьми;

- кмітливість - здатність розуміти сутність явищ, з'ясовувати причини і наслідки, визначати головне;

- наполегливість - виявлення сили волі, завзяття, вміння доводити справу до кінця;

- самовладання - здатність контролювати свої почуття, поведінку у складних ситуаціях;

- працездатність - витривалість, здатність вести напружену роботу, тривалий час не втомлюватися;

- спостережливість - уміння бачити мимохідь визначити особливе, зберегти в пам'яті деталі;

- самостійність - незалежність у рішеннях, уміння самому знаходити шляхи виконання завдання, брати на себе відповідальність;

- організованість - здатність підпорядкувати себе необхідному режиму роботи, планувати діяльність, виявляти послідовність, зібраність [3; с 60-61].

Отже, такі якості, як: компетентність, активність, ініціативність, товариськість, кмітливість, наполегливість, самовладання, працездатність, спостережливість, самостійність, організованість, швидкість реакції, необхідно виховувати у студентів медичних закладів.

Висвітлені якості дозволяють студенту медику швидко встановлювати психологічний контакт з іншими людьми (хворими), справляти приємне враження про себе, доносити до хворих на відповідному їх віку рівні нову інформацію. 


\section{Література}

1. Винославська О. В. Психологічні особливості студентської групи / О. В. Винославська // Практична психологія та соціальна робота. - 2005. - № 7. - С. 65-87. 2. Зимняя И. А. Педагогическая психология / И. А. Зимняя - Ростов-на-Дону : Феникс, 1997. - 480 с. З. Лутошкин А. Н. Как вести за собой: Старшеклассникам об основах орг. Работы / под ред. Б. 3. Вульфова. 3-е изд., перераб, и доп. - М. : Просвещение, 1986. - 208 с.: ил. 4. Тлумачний словник української мови / за ред. Д. Г. Гринчишина. - 3-е вид., перероб. і допов. - К. : Освіта, 1999 - 302 с.

\section{ПЕДАГОГІЧНІ УМОВИ ПІДГОТОВКИ МАЙБУТНІХ ВИХОВАТЕЛІВ ДОШКІЛЬНИХ НАВЧАЛЬНИХ ЗАКЛАДІВ ДО РОБОТИ 3 ДІТЬМИ 3 ФУНКЦІОНАЛЬНИМИ ПОРУШЕННЯМИ ОПОРНО-РУХОВОГО АПАРАТУ}

Шовкопляс О. М. Педагогічні умови підготовки майбутніх вихователів дошкільних навчальних закладів до роботи з дітьми з функціональними порушення опорно-рухового апарату.

У статті розглядається структура необхідних педагогічних умов, для ефективного процесу формування готовності майбутніх вихователів до роботи 3 дошкільниками, що мають функціональні порушення опорно-рухового апарату.

Ключові слова: педагогічні умови; майбутні вихователі, дошкільники.

Шовкопляс О.Н. Педагогические условия подготовки будущих воспитателей дошкольных образовательных учреждений к работе с детьми с функциональными нарушениями опорнодвигательного аппарата.

В статье рассматривается структура необходимых педагогических условий для эффективного процесса формирования готовности будущих воспитателей к работе с дошкольниками, которые имеют функциональные нарушения опорно-двигательного аппарата.

Ключевые слова: педагогические условия; будущие воспитатели, дошкольники.

Shovkoplyas O.M. Pedagogical conditions of future teachers of preschool education to work with children with functional disorders of the musculoskeletal system.

This paper deals with determination of the necessary educational conditions for the efficient process of formation of future teachers to work with preschool children with functional disorders opine motor system.

Key words: teaching conditions, future educators, preschool children.

У Національній доктрині розвитку освіти України у XXI столітті турботу про здоров'я підростаючого покоління визначено пріоритетним завданням. Головну увагу акцентовано на тому, що заклади освіти повинні створювати відповідні умови для збереження й укріплення здоров'я кожної дитини. Однак, останнім часом, за даними НДІ гігієни і профілактики захворювань дітей, підлітків та молоді, у нашій державі виявлено несприятливу тенденцію до погіршення стану здоров'я дошкільників: знизилося число абсолютно здорових дітей і збільшилося число дітей, що мають різні відхилення у стані здоров'я, хронічні захворювання. За даними академіка Л. Бадаляна, більше 50 \% дошкільників 3-6 років мають функціональні відхилення, 3 них: 30-40 \% опорно-рухового апарату, 20-25 \% дихальної системи, у 30-40\% дітей молодшого і 20-30\% старшого дошкільного віку фіксуються неврологічні вияви.

Особливе занепокоєння викликає той факт, що у дітей 3-6 років хвороби кістковом'язової системи (порушення постави, пласкостопість, сколіоз тощо) займають 1-е місце за поширеністю: порушення постави виявлено майже у 80 \%, а пласкостопість - у $40 \%$ дошкільників. Функціональні відхилення визначаються у 40-50 \% цих дітей, початкові 